\section{Warm-season Turfgrass Species Generate Sports Surfaces with Different Playability}

\author{
Filippo Lulli ${ }^{1}$, Claudia de Bertoldi ${ }^{1,4}$, Roberto Armeni $^{2}$, \\ Lorenzo Guglielminetti ${ }^{3}$, and Marco Volterrani ${ }^{3}$
}

\begin{abstract}
ADDITIONAL INDEX WORDS. bermudagrass, seashore paspalum, zoysiagrass, standards, natural turf, sports turf, football

SUMMARY. Synthetic sports surfaces are increasingly subject to standardization of athlete-surface and ball-surface interactions (playability parameters). Such standardizations have led to an increase in the level of the engineering and predictability of these surfaces, and as such may be beneficial also for natural turf. In warm and temperate climates, many natural turf sports surfaces are established with warmseason $\left(\mathbf{C}_{4}\right)$ turfgrass species due to their suitability to the environment in such areas. This study was aimed at evaluating the Féderation Internationale de Football Association (FIFA)-standard playing characteristics of different sports turf surfaces obtained from three commonly used $\mathrm{C}_{4}$ turfgrass species: 1) 'Tifway 419' hybrid bermudagrass (Cynodon dactylon var. dactylon $\times$ C. transvaalensis), 2) 'Zeon' manilagrass (Zoysia matrella), and 3) 'Salam' seashore paspalum (Paspalum vaginatum) for factors concerning leaf tissue (silica, lignin, water content) and canopy structure (shoot density, leaf architecture, stolon density, etc.). Results showed that surfaces of different $\mathrm{C}_{4}$ turfgrass species generate different playability parameters, with seashore paspalum being a harder faster surface, manilagrass being a softer slower surface, and hybrid bermudagrass showing intermediate characteristics. These playing quality results were associated with certain specific canopy biometrical/morphological parameters such as shoot density, horizontal stem density (HSD), leaf section, and, to a lesser extent, to certain plant tissue compounds (lignin, silica).
\end{abstract}

$\mathrm{F}$ éderation Internationale des Football Associations' (Zurich, Switzerland) regulation of the materials and methods associated with the construction of synthetic turf pitches (FIFA, 2012a, 2012b) has led to the development of widely accepted synthetic grass sport surfaces. This improvement was achieved thanks to the standardization procedures, which were implemented through the use of a series of machinery and instruments for laboratory and field evaluation of synthetic turf: such methods show great potential for natural turf evaluation (Lulli et al., 2010).

The bulk of research on the playability of natural turf football pitches on cool-season turfgrass species was carried out in the 1980 to 1990 period, with some research papers reaching the goal of setting preferable playing characteristics parameters for football pitches (Baker et al., 1992)

\footnotetext{
${ }^{1}$ Turf Europe Srl, Via Malasoma 24, 56121 Pisa, Italy ${ }^{2}$ Labosport Italia Srl, Via Monza 16, 23870 Cernusco Lombardone, Italy

${ }^{3}$ Department of Agriculture, Food and Environment, University of Pisa, Via del Borghetto 80, 56124 Pisa, Italy

${ }^{4}$ Corresponding author. E-mail: claudia.debertoldi@ turfeurope.eu.
}

and methods (Baker and Canaway, 1993). Research has focused mainly in comparing different playability parameters. Most of these works have concentrated on comparing different playing characteristics obtained by different construction methods and pitch drainage layouts (Baker and Canaway, 1991), different turfgrass mowing heights (Grossi et al., 2003; Rogers and Waddington, 1989), comparisons between synthetic and natural turf pitches (Baker and Woollacott, 2005), and different sports field construction methods (Canaway, 1983). The playability results generated by different turfgrass species have been less frequently investigated ( $\mathrm{McNitt}$ et al., 2003; Orchard et al., 2005) or reviewed (Chivers, 2008), but have consistently highlighted the fact that different turfgrass species generate sports surfaces with different playing characteristics.

Between latitudes $40^{\circ} \mathrm{N}$ and $40^{\circ} \mathrm{S}$ (and increasingly between latitudes $43^{\circ} \mathrm{N}$ and $43^{\circ} \mathrm{S}$ ) football pitches, including some famous, high-capacity stadiums, make use of warm-season $\left(\mathrm{C}_{4}\right)$ turfgrass species. The reasons for the widespread use of these species lie in their great adaptability to wide $\mathrm{pH}$ and salinity ranges (Marcum, 1999), high temperature and drought tolerance (Croce et al., 2004; Pompeiano et al., 2012), pest resistance and a high colonization and recuperation capability deriving from their stoloniferous and/or rhizomatous growth habit (Beard, 1973), and wear tolerance (Brosnan and Deputy, 2009). Furthermore, the ongoing implementation of recent legislation (European Council, 2009) effectively limiting the use of pesticides in the European Union (EU) in urban green area (including sports fields) could lead to an even wider adoption of $\mathrm{C}_{4}$ turfgrass for sports fields in the temperate climate areas.

In previous studies, FIFA-standard tissue strength (Alamar et al., 2008; Lulli et al., 2011) and wear simulation (Lulli et al., 2012) tests have been conducted to evaluate physiological and morphological features of

\begin{tabular}{cllc}
\hline $\begin{array}{l}\text { Units } \\
\text { To convert U.S. to SI, } \\
\text { multiply by }\end{array}$ & U.S. unit & SI unit & $\begin{array}{l}\text { To convert SI to U.S., } \\
\text { multiply by }\end{array}$ \\
\hline 0.3048 & $\mathrm{ft}$ & $\mathrm{m}$ & 3.2808 \\
0.0929 & $\mathrm{ft}^{2}$ & $\mathrm{~m}^{2}$ & 10.7639 \\
2.54 & inch $(\mathrm{es})$ & $\mathrm{cm}$ & 0.3937 \\
25.4 & inch $(\mathrm{es})$ & $\mathrm{mm}$ & 0.0394 \\
6.4516 & inch & $\mathrm{cm}^{2}$ & 0.1550 \\
645.1600 & inch & $\mathrm{mm}$ & 0.0016 \\
0.1550 & inch/inch & $\mathrm{cm}^{2} \cdot \mathrm{cm}^{-3}$ & 6.4516 \\
16.3871 & inch & $\mathrm{cm}$ & 0.0610 \\
0.4536 & $\mathrm{lb}$ & $\mathrm{kg}$ & 2.2046 \\
1.1209 & $\mathrm{lb} / \mathrm{acre}$ & $\mathrm{kg} \cdot \mathrm{ha}^{-1}$ & 0.8922 \\
4.4482 & $\mathrm{lbf}$ & $\mathrm{N}$ & 0.2248 \\
1.3558 & $\mathrm{lbf}$ & $\mathrm{N} \cdot \mathrm{m}^{3}$ & 0.7376 \\
0.4470 & $\mathrm{mph}$ & $\mathrm{m} \cdot \mathrm{s}^{-1}$ & 2.2369 \\
28,350 & $\mathrm{OZ}$ & $\mathrm{mg}$ & $3.5274 \times 10^{-5}$ \\
0.001 & $\mathrm{ppm}$ & $\mathrm{mg} \cdot \mathrm{g}^{-1}$ & 1000 \\
0.0069 & $\mathrm{psi}$ & $\mathrm{MPa}$ & 145.0377 \\
$\left({ }^{\circ} \mathrm{F}-32\right) \div 1.8$ & ${ }^{\circ} \mathrm{F}$ & ${ }^{\circ} \mathrm{C}$ & $\left({ }^{\circ} \mathrm{C} \times 1.8\right)+32$ \\
& & &
\end{tabular}


$\mathrm{C}_{3}$ (plants with a $\mathrm{C}_{3}$ metabolic pathway for carbon fixation) and $\mathrm{C}_{4}$ turfgrass species, with investigations on the contribution to the results for turfgrass canopy morphological parameters, and plant key constituents (mainly lignin and silica). These two common plant tissue compounds are often called upon to explain wear tolerance in both warm-season (Trenholm et al., 2000) and cool-season turfgrass species (Shearman and Beard, 1975), and generally seem to affect most of the mechanical properties of turfgrass leaves.

However, since no previous research was found that compares the playability characteristics of different $\mathrm{C}_{4}$ turfgrass surfaces under identical root zone and with identical agronomic management practices, this study was conceived to evaluate the playing characteristics of turfgrasses obtained from the following $\mathrm{C}_{4}$ turfgrasses that are commonly used in soccer fields and in general sports surfaces: 1) 'Tifway 419' hybrid bermudagrass, 2) 'Zeon' manilagrass, and 3) 'Salam' seashore paspalum. To increase the understanding of how turfgrass biological and morphological factors effectively influence the playing characteristics of a turfgrass surface, the playability results obtained on the field through a complete set of FIFAstandard tests [with the addition of penetrography and Clegg impact soil tester $[0.5 \mathrm{~kg}$ hammer dropped from $0.3 \mathrm{~m}$ (Clegg, 1976)] were plotted against laboratory analyses of plant tissue lignin and silica, and relevant plant and canopy morphological parameters.

\section{Materials and methods}

A trial was conducted on June to Sept. 2012 at the turfgrass research station of the Department of Agriculture, Food and Environment of the
University of Pisa (lat. $43^{\circ} 40^{\prime} \mathrm{N}$, long. $10^{\circ} 19^{\prime} \mathrm{E}$; elevation $\left.6 \mathrm{~m}\right)$, on mature and healthy 8-year-old turfgrass swards of 1) 'Tifway 419' hybrid bermudagrass, 2) 'Zeon' manilagrass, and 3) 'Salam' seashore paspalum. Plots initially were established in Spring 2004 by sprigging on a silt-loam soil, and topdressed twice (17 July and 6 Aug. 2012) with $1-\mathrm{cm}$ layers of silica sand at each application. Plots were mowed weekly from June to Sept. 2012 at $1.5 \mathrm{~cm}$ with a reel mower and clippings removed. Mowing height was set at $1.5 \mathrm{~cm}$, as this is a generally accepted height for hybrid bermudagrass sports fields (Brosnan and Deputy, 2007), while no clear indications are available on the preferable mowing height for manilagrass or seashore paspalum football fields. This mowing height was maintained also throughout the tests by mowing the day before the tests. Irrigation was two weekly applications $(20 \mathrm{~mm} \times 2=40 \mathrm{~mm})$ via an automated pop-up sprinkler system to reintegrate effective evapotranspiration (weekly historical average effective evapotranspiration for the same period for bermudagrass $=40 \mathrm{~mm}$ /week). $\mathrm{No}$ fungicide applications or weed control was necessary or carried out throughout this study. Fertilization was applied on 19 June, 23 July, 8 Aug., and 6 Sept. 2012 , for a total of $238 \mathrm{~kg} \cdot \mathrm{ha}^{-1}$ nitrogen $(\mathrm{N}), 26 \mathrm{~kg} \cdot \mathrm{ha}^{-1}$ phosphorous $(\mathrm{P})$, and $66 \mathrm{~kg} \cdot \mathrm{ha}^{-1}$ potassium (K) (Table 1). The experimental design was a randomized complete block design with four replications, each plot was $100 \mathrm{~m}^{2}$ and each block was $400 \mathrm{~m}^{2}$.

FIELD PLAYING CHARACTERISTICS TESTs. Field tests on football playing parameters were carried out on single date (19 Sept. 2012) with four readings per plot as per FIFA test requirement manual [see Table 2 for a brief description of FIFA-standard football playability tests (FIFA, 2012a)]: ball rebound (FIFA Test Method 01), angle ball rebound (FIFA Test Method 02), ball roll (FIFA Test Method 03), shock absorption [FIFA Test Method 04a-Shock absorption (sometimes referred to as "force reduction") is the ability of a surface to reduce impact forces when compared with a rigid surface, such as concrete; for instance, a shock absorption of $70 \%$ on a sports turf area means that it is $70 \%$ softer than concrete], standard vertical deformation (FIFA Test Method $05 a$-vertical deformation values indicate the ability of the surface to deform under load), rotational resistance (FIFA Test Method 06), surface hardness (Clegg, 1976), and soil resistance to penetration by van Wijk (1980) using a penetrograph with $1-\mathrm{cm}^{2}$ point $(06.02$; Eijkelkamp Agrisearch Equipment, Giesbeek, Netherlands). All tests were carried out at $18-25^{\circ} \mathrm{C}$ in dry surface conditions, with a wind speed $<1.0 \mathrm{~m} \cdot \mathrm{s}^{-1}$. Plots were irrigated to saturation and allowed to drain for $48 \mathrm{~h}$ (to field capacity) to obtain similar soil moisture across the experimental plots.

Biometrics OF SINGLE PLANT ORGANS. On the same date four core samples per plot were collected [plugs $66.44 \mathrm{~cm}^{2} \times 4 \mathrm{~cm}$ deep $\left(265.8 \mathrm{~cm}^{3}\right.$ total volume)] to be surveyed for several plant and canopy parameters.

Stolon diameter and leaf blade thickness (millimeters) were measured via a digital feeler gauge (Absolute IP54; Mitutoyo Corp., Kawasaki, Japan) with a $0.5-\mathrm{N}$ max load and $\pm 2 \mathrm{~nm}$ error. Leaf blade width, thickness at midleaf, and stolon diameter at midinternode was measured using the

Table 1. Fertilization program applied to experimental plots of 'Tifway 419' hybrid bermudagrass, 'Zeon' manilagrass, and 'Salam' seashore paspalum to guarantee optimum nutrient availability during the trial period, 19 June 2012 to 6 Sept. 2012.

\begin{tabular}{|c|c|c|c|c|c|c|c|c|}
\hline Date & Fertilizer type & Rate $(\mathbf{k g})^{\mathrm{z}}$ & $\mathbf{N}(\%)^{y}$ & $\mathbf{P}(\%)^{\mathrm{y}}$ & $\mathrm{K}(\%)^{\mathrm{y}}$ & Total N & Total P $\left(\mathrm{kg} \cdot \mathrm{ha}^{-1}\right)^{\mathrm{z}}$ & Total K \\
\hline 19 June 2012 & Diammonium phosphate & 18 & 18 & 20 & 0 & 27 & 13 & 0 \\
\hline 19 June 2012 & Urea & 12 & 46 & 0 & 0 & 46 & 0 & 0 \\
\hline 19 June 2012 & Potassium sulphate & 12 & 0 & 0 & 40 & 0 & 0 & 33 \\
\hline 23 July 2012 & Urea & 24 & 46 & 0 & 0 & 92 & 0 & 0 \\
\hline 6 Sept. 2012 & Diammonium phosphate & 18 & 18 & 20 & 0 & 27 & 13 & 0 \\
\hline 6 Sept. 2012 & Urea & 12 & 46 & 0 & 0 & 46 & 0 & 0 \\
\hline
\end{tabular}

${ }^{\mathrm{y}} \mathrm{l} \mathrm{kg}=2.2046 \mathrm{lb}, \mathrm{l} \mathrm{kg} \cdot \mathrm{ha}^{-1}=0.8922 \mathrm{lb} /$ acre.

${ }^{y}$ Nitrogen $(\mathrm{N})$, phosphorous $(\mathrm{P})$, potassium $(\mathrm{K})$. 
Table 2. List and brief description of Féderation Internationale des Football Associations (FIFA)-standard football playability tests carried out on 'Tifway 419' hybrid bermudagrass, 'Zeon' manilagrass, and 'Salam' seashore paspalum (FIFA, 2012a).

\begin{tabular}{|c|c|c|}
\hline $\begin{array}{l}\text { FIFA Test } \\
\text { Method no. }\end{array}$ & Title of test & Brief description \\
\hline 01 & Determination of ball rebound & $\begin{array}{l}\text { A ball is released from } 2 \mathrm{~m}(6.6 \mathrm{ft}) \text { and the height of its rebound from the } \\
\text { surface calculated. }\end{array}$ \\
\hline 02 & $\begin{array}{l}\text { Determination of angle } \\
\text { ball rebound }\end{array}$ & $\begin{array}{l}\text { A ball is projected, at a specified speed and angle, onto the surface and the } \\
\text { angle ball rebound calculated from the ratio of the ball's velocity just after } \\
\text { impact to the velocity just before impact. }\end{array}$ \\
\hline $04 \mathrm{a}$ & $\begin{array}{l}\text { Determination of shock } \\
\text { absorption }\end{array}$ & $\begin{array}{l}\text { A mass with a spring attached to it is allowed to fall onto the test piece and from } \\
\text { the recorded acceleration of the mass from the moment of release till after } \\
\text { its impact with the test piece the force reduction is calculated by comparing } \\
\text { the percentage reduction in this force relative to a reference force } \\
\text { (theoretical force on concrete). }\end{array}$ \\
\hline 06 & $\begin{array}{l}\text { Determination of rotational } \\
\text { resistance }\end{array}$ & $\begin{array}{l}\text { The torque required to rotate a loaded test foot in contact with the surface } \\
\text { is measured and the rotational resistance calculated. }\end{array}$ \\
\hline
\end{tabular}

digital ruler function of a $20 \times-200 \times$ digital microscope (AM413MT-DinoLite; AnMo Electronics Corp., New Taipei City, Taiwan). All measurements were made on 20 samples for each organ (five organs per core sample per experimental unit; fourth node from the apical tip) randomly collected from each plot. Tissue sections were calculated and expressed them as follows:

$$
\begin{aligned}
& \text { Leaf section (square millimeters) } \\
& =\text { leaf width } \times \text { leaf thickness } \\
& \text { Horizontal stem section } \\
& \quad[\text { HSS (square millimeters })] \\
& =\Pi \times\left(\frac{\text { stolon diameter }}{2}\right)^{2}
\end{aligned}
$$

BiOMETRICS OF TURFgRASS CANOPY. Live shoots were counted from each $66.44-\mathrm{cm}^{2}$ core plug. Data were calculated and expressed as follows:

$$
\begin{aligned}
& \text { Shoot density } \\
& \text { (shoots per square centimeter) } \\
& \quad=\frac{\text { live shoots }}{66.44}
\end{aligned}
$$

Horizontal stem density $[($ HSD $)=$ the linear extent of all stolons present in a cubic centimeter of sod] was evaluated by measuring and summing the length of all the stolon fractions found in the plugs. Data were calculated and expressed as follows:

HSD (centimeters per cubic centimeter)

$$
=\frac{\text { total stolon length }}{256.8}
$$

LIGNIN AND SILICA LABORATORY Assays. On 19 Sept. 2012, plant organs were harvested and stored at $-80{ }^{\circ} \mathrm{C}$. Samples were $\approx 0.2 \mathrm{mg}$ of fully expanded leaf tissue and stolons from nodes older than the fourth from apex. These were placed in plastic Eppendorf tubes (HamburgEppendorf, Hamburg, Germany) until assayed (four samples for silica assay, four for lignin assay).

Leaf tissue samples were laboratory tested for their content in the following substances: 1) Lignin: Lignin content was extracted by using the thioglycolic acid extraction system as described in Brinkmann et al. (2002) and quantified spectrophotometrically at $335 \mathrm{~nm}$. Calibration curves were generated by subjecting increasing amounts of commercial lignin (lignin alkali by Aldrich Italy, Milan, Italy) to the same procedure. 2 ) Silica: Silica content was analyzed using an autoclaved-induced digestion as reported in Elliott and Snyder (1991). We measured concentration of silica spectrophotometrically at $650 \mathrm{~nm}$. Calibration curves were generated by subjecting increasing amounts of commercial silicates (Aldrich Italy nonahydrate metasilicate) to the same procedure. 3 ) Dry matter content: All samples were dried in an oven at $60{ }^{\circ} \mathrm{C}$ for 1 week and then weighed.

All spectrophotometric quantifications were carried out with a spectrophotometer (U-3200 ultraviolet/ Visible; Hitachi, Tokyo, Japan).

STATISTICAL ANALYSES. All statistical analyses were made using COSTAT 6.400 software (CoHort Software, Monterey, CA). Bartlett's test was used for homogeneity on all data sets. Log transformed was used only for non-normally distributed data sets until normal distribution was obtained.

For all biometric, laboratory, and shoot data, species effects were analyzed via analysis of variance, and Tukey's honestly significant difference test at $P \leq 0.05$ was used to detect differences between means.

All playing characteristics, plant biometric, canopy biometric, and leaf tissue constituent data were correlated using Pearson product-moment correlation coefficient $(P \leq 0.05$ significance level).

\section{Results}

Plant and canopy biometrics. All plant and canopy biometric traits 
were found to carry statistically significant species effects $(P \leq 0.05)$, with the exception of leaf thickness (see Table 3 for all plant/canopy biometrics).

'Zeon' had the thinnest stolons (HSS $\left.=1.0 \mathrm{~mm}^{2}\right)$, with the highest density of stolons per cubic centimeter $\left(\mathrm{HSD}=2.9 \mathrm{~cm} \cdot \mathrm{cm}^{-3}\right)$. Conversely 'Salam' had the thickest stolons $\left(3.6 \mathrm{~mm}^{2}\right)$ and the lowest HSD $\left(0.7 \mathrm{~cm} \cdot \mathrm{cm}^{-3}\right)$. 'Tifway 419' exhibited intermediate traits for HSS $\left(3.1 \mathrm{~mm}^{2}\right)$ and an HSD more similar to 'Salam' $\left(0.9 \mathrm{~cm} \cdot \mathrm{cm}^{-3}\right)$.

'Salam' showed the least dense canopy $\left(3.8\right.$ shoots $\left./ \mathrm{cm}^{2}\right)$, while 'Tifway 419' and 'Zeon' had higher and similar canopy densities (5.4 and 5.8 shoots $/ \mathrm{cm}^{2}$, respectively).

'Salam' also showed the widest leaf $(2.3 \mathrm{~mm})$ compared with similarly textured 'Tifway 419' and 'Zeon' (1.9 mm for both) and, since the differences in leaf thickness were not found to be statistically significant, these differences are carried over into leaf section with a higher section for 'Salam' $\left(0.4 \mathrm{~mm}^{2}\right)$, compared with similarly thick 'Tifway 419' $\left(0.3 \mathrm{~mm}^{2}\right)$ and 'Zeon' $\left(0.2 \mathrm{~mm}^{2}\right)$

LIGNIN, SILICA, DRY MATTER CONTENT Statistically significant $(P \leq$ $0.05)$ species effect was found for all assayed leaf tissue constituents (see Table 4 for all plant tissue constituents).

'Zeon' showed the highest leaf silica $\left[5.5 \mathrm{mg} \cdot \mathrm{g}^{-1}\right.$ by fresh weight $(\mathrm{FW})]$ and lignin content (22.9 $\mathrm{mg} \cdot \mathrm{g}^{-1} \mathrm{FW}$ ), with the highest concentration of dry matter (31.8\%). Conversely, 'Salam' leaf had the lowest silica $\left(3.8 \mathrm{mg} \cdot \mathrm{g}^{-1} \mathrm{FW}\right)$ and lignin content $\left(12.2 \mathrm{mg} \cdot \mathrm{g}^{-1} \mathrm{FW}\right)$, with the lowest concentration of dry matter (21.2\%). 'Tifway 419' had similar silica and lignin and not statistically different from 'Salam', but a dry matter content was intermediate between 'Zeon' and 'Salam' (25.9\%).

Playing characteristics. The three species showed no statistically significant differences for angle ball rebound, with all three returning values (54.9\% to $58.4 \%$ ) within the FIFA 2-Star range, nor for penetrograph-measured maximum hardness (see Table 5 for all playability parameters).

'Tifway 419' and 'Zeon' had similar ball roll $(7.6$ and $7.8 \mathrm{~m}$, respectively), hardness (both with 46 $\left.\mathrm{G}_{\max }\right)$, angle ball rebound $(57.0 \%$ and
$54.9 \%$, respectively), shock absorption (71.2\% and $71.0 \%$, respectively), and vertical deformation $(5.8$ and $6.1 \mathrm{~mm}$, respectively). The only aspects in which 'Tifway 419' and 'Zeon' differed ( $P \leq$ $0.05)$ was maximum hardness depth with a very shallow $1.3 \mathrm{~cm}$ for 'Zeon' and a much deeper $7.3 \mathrm{~cm}$ for 'Tifway $419^{\prime}$, and traction with 42.2 Newton meters $(\mathrm{N} \cdot \mathrm{m})$ for 'Zeon' and $39.4 \mathrm{~N} \cdot \mathrm{m}$ for 'Tifway 419'.

'Salam' seashore paspalum emerged as the variety generating the hardest playing surface, with the highest hardness (Clegg impact soil tester) $\left(60 \mathrm{G}_{\max }\right.$, where $\mathrm{G}_{\max }=$ maximum negative acceleration on impact in gravities/acceleration due to gravity), the lowest vertical deformation $(3.8 \mathrm{~mm})$, and the lowest shock absorption $(61.4 \%)$. The depth at which the penetrograph-measured maximum hardness was $9 \mathrm{~cm}$, and by the low traction values was $33.0 \mathrm{~N} \cdot \mathrm{m}$.

The hardness of the 'Salam' surface generates the "fastest" surface with the longest ball roll $(9.9 \mathrm{~m})$ and the highest ball rebound $(86 \mathrm{~cm})$.
CORRELATIONS BETWEEN PLAYING CHARACTERISTICS AND PLANT/CANOPY BIOMETRICS OR LEAF COMPOUNDS. Shoot density was negatively correlated with the hardness of the playing surface, both in terms of Cleggmeasured hardness $(r=-0.90)$ and of Berlin Athlete-measured parameters (shock absorption $\mathrm{r}=0.87$; vertical deformation $\mathrm{r}=0.90$ ) (Tables 6 and 7). Shoot densities had a strong negative correlation with ball roll $(\mathrm{r}=-0.91)$, vertical ball rebound $(\mathrm{r}=-0.76)$, and angle ball rebound $(\mathrm{r}=-0.73)$, while traction was positively correlated with shoot density $(\mathrm{r}=0.70)$.

Taken singularly, leaf thickness and leaf width showed little correlation with playing parameters; however, the resulting (calculated) leaf section was remarkably linked to the same parameters as shoot density, but with the opposite contribution.

Dry weight is negatively correlated with Clegg-measured hardness $(\mathrm{r}=-0.76)$, and positively correlated with Berlin Athlete-measured shock absorption $(\mathrm{r}=0.68)$ and vertical

Table 3. Horizontal stem section (HSS), horizontal stem density (HSD), shoot density, leaf width, leaf thickness, leaf section in 'Tifway 419' hybrid bermudagrass, 'Zeon' manilagrass, and 'Salam' seashore paspalum sampled on 19 Sept. 2012.

\begin{tabular}{lcccccc}
\hline Variety & $\begin{array}{c}\text { HSS } \\
\left(\mathbf{m m}^{2}\right)^{\mathrm{z}}\end{array}$ & $\begin{array}{c}\text { HSD } \\
\left(\mathbf{c m} \cdot \mathbf{c m}^{-3}\right)^{\mathrm{z}}\end{array}$ & $\begin{array}{c}\text { Shoot } \\
\text { density } \\
\left(\text { shoots } / \mathbf{c m}^{2}\right)^{\mathrm{z}}\end{array}$ & $\begin{array}{c}\text { Leaf width } \\
(\mathbf{m m})^{\mathrm{z}}\end{array}$ & $\begin{array}{c}\text { Leaf } \\
\text { thickness } \\
(\mathbf{m m})\end{array}$ & $\begin{array}{c}\text { Leaf } \\
\text { section } \\
\left(\mathbf{m m}^{2}\right)\end{array}$ \\
\hline Tifway 419 & $3.1 \mathrm{ab}^{\mathrm{y}}$ & $0.9 \mathrm{~b}$ & $5.4 \mathrm{a}$ & $1.9 \mathrm{~b}$ & $0.2 \mathrm{a}$ & $0.3 \mathrm{~b}$ \\
Zeon & $1.0 \mathrm{~b}$ & $2.9 \mathrm{a}$ & $5.8 \mathrm{a}$ & $1.9 \mathrm{~b}$ & $0.1 \mathrm{a}$ & $0.2 \mathrm{~b}$ \\
Salam & $3.6 \mathrm{a}$ & $0.7 \mathrm{~b}$ & $3.8 \mathrm{~b}$ & $2.3 \mathrm{a}$ & $0.1 \mathrm{a}$ & $0.4 \mathrm{a}$ \\
& & & ANOVA & & & \\
Treatment & $*$ & $* * *$ & $* *$ & $* * *$ & NS & $* *$ \\
\hline
\end{tabular}

${ }^{\mathrm{z}} 1 \mathrm{~mm}^{2}=0.0016$ inch $^{2}, 1 \mathrm{~cm} \cdot \mathrm{cm}^{-3}=6.4516 \mathrm{inch} / \mathrm{inch}^{3}, 1$ shoot $/ \mathrm{cm}^{2}=0.1550$ shoot $/ \mathrm{inch}^{2}, 1 \mathrm{~mm}=0.0394$ inch. ${ }^{y}$ Means followed by the same letter in a column do not differ significantly via Tukey's honestly significant difference test at $P \leq 0.05$

NS, $* * *, * * *$ Nonsignificant or significant at $P \leq 0.05,0.01,0.001$, respectively

Table 4. Silica, lignin, and dry matter percentage in leaves of 'Tifway 419' hybrid bermudagrass, 'Zeon' manilagrass, and 'Salam' seashore paspalum sampled on 19 Sept. 2012.

\begin{tabular}{lccc}
\hline Variety & $\begin{array}{c}\text { Silica } \\
\left(\mathbf{m g} \cdot \mathbf{g}^{-\mathbf{1}} \mathbf{F W}\right)^{\mathbf{z}}\end{array}$ & $\begin{array}{c}\text { Lignin } \\
\left(\mathbf{m g} \cdot \mathbf{g}^{-1} \mathbf{F W}\right)\end{array}$ & $\begin{array}{c}\text { Dry matter } \\
(\%)\end{array}$ \\
\hline Tifway 419 & $4.3 \mathrm{~b}^{\mathrm{y}}$ & $13.7 \mathrm{~b}$ & $25.9 \mathrm{~b}$ \\
Zeon & $5.5 \mathrm{a}$ & $22.9 \mathrm{a}$ & $31.8 \mathrm{a}$ \\
Salam & $3.8 \mathrm{~b}$ & $12.2 \mathrm{~b}$ & $21.2 \mathrm{c}$
\end{tabular}

\begin{tabular}{|c|c|c|}
\hline \multicolumn{2}{|c|}{ ANUVA } & \multirow[b]{2}{*}{ ** } \\
\hline Treatment & ** & \\
\hline
\end{tabular}


Table 5. Ball roll, surface hardness, maximum hardness (canopy + soil), maximum hardness depth (canopy + soil), traction, vertical ball rebound, angular ball rebound, shock absorption, vertical deformation in 'Tifway 419' hybrid bermudagrass, 'Zeon' manilagrass, and 'Salam' seashore paspalum. Accepted or recommended pitch range values for Féderation Internationale des Football Associations (FIFA) 1-Star [synthetic turf fields for non-professional football training and competitions (FIFA, 2012b)], FIFA 2-Star [synthetic turf fields for professional football competitions (FIFA, 2012b)], and natural turf (Baker et al., 1992). Test date was 19 Sept. 2012.

\begin{tabular}{|c|c|c|c|c|c|c|c|c|c|}
\hline Variety & $\begin{array}{c}\text { Ball } \\
\text { roll }(\mathbf{m})^{z}\end{array}$ & $\begin{array}{c}\text { Hardness } \\
\left(G_{\max }\right)^{y}\end{array}$ & $\begin{array}{c}\text { Maximum } \\
\text { hardness } \\
(\mathrm{MPa})^{\mathrm{z}}\end{array}$ & $\begin{array}{c}\text { Maximum } \\
\text { hardness } \\
\text { depth }(\mathrm{cm})^{z}\end{array}$ & $\begin{array}{c}\text { Traction } \\
(\mathbf{N} \cdot \mathbf{m})^{\mathrm{z}}\end{array}$ & $\begin{array}{c}\text { Vertical ball } \\
\text { rebound } \\
(\mathrm{cm})\end{array}$ & $\begin{array}{c}\text { Angle } \\
\text { ball } \\
\text { rebound (\%) }\end{array}$ & $\begin{array}{c}\text { Shock } \\
\text { absorption } \\
(\%)\end{array}$ & $\begin{array}{c}\text { Vertical } \\
\text { deformation } \\
(\mathrm{mm})^{\mathrm{z}}\end{array}$ \\
\hline Zeon & $7.8 \mathrm{~b}$ & $46 \mathrm{~b}$ & $3.9 \mathrm{a}$ & $1.3 \mathrm{c}$ & $42.2 \mathrm{a}$ & $81.8 \mathrm{~b}$ & $54.9 \mathrm{a}$ & $71.0 \mathrm{a}$ & $6.1 \mathrm{a}$ \\
\hline Salam & $9.9 \mathrm{a}$ & $60 a$ & $3.3 \mathrm{a}$ & $9.0 \mathrm{a}$ & $33.0 \mathrm{c}$ & $86.0 \mathrm{a}$ & $58.4 \mathrm{a}$ & $61.4 \mathrm{~b}$ & $3.8 \mathrm{~b}$ \\
\hline FIFA 1-Star & $4-10$ & n.a. ${ }^{\mathrm{w}}$ & n.a. & n.a. & $25-50$ & $60-100$ & $45-80$ & $60-70$ & $4-11$ \\
\hline FIFA 2-Star & $4-8$ & n.a. & n.a. & n.a. & $30-45$ & $60-85$ & $45-80$ & $55-70$ & $4-10$ \\
\hline Natural turf & $3-12$ & $20-80$ & $\geq 1.4$ & n.a. & $\geq 25$ & $40-100$ & n.a. & n.a. & n.a. \\
\hline
\end{tabular}

${ }^{\mathrm{z}} 1 \mathrm{~m}=3.2808 \mathrm{ft}, \mathrm{l} \mathrm{MPa}=145.0377 \mathrm{psi}, \mathrm{l} \mathrm{cm}=0.3937 \mathrm{inch}, 1$ Newton meter $(\mathrm{N} \cdot \mathrm{m})=1$ Joule $=0.7376 \mathrm{lbf}, 1 \mathrm{~mm}=0.0394 \mathrm{inch}$.

${ }^{\mathrm{y}} \mathrm{G}_{\max }=$ maximum negative acceleration on impact/acceleration due to gravity (adimensional).

${ }^{x}$ Means followed by the same letter in a column do not differ significantly via Tukey's honestly significant difference test at $P \leq 0.05$.

wot available.

Ns, $* * *, * * *$ Nonsignificant or significant at $P \leq 0.05,0.01,0.001$, respectively.

Table 6. Pearson product-moment correlation coefficient ( $r$ ) between playing parameters (tests carried out 19 Sept. 2012) and plant and canopy parameters (leaf and canopy samples collected on 19 Sept. 2012) across the three tested species ('Tifway 419' hybrid bermudagrass, 'Zeon' manilagrass, 'Salam' seashore paspalum).

\begin{tabular}{lcccccc}
\hline Parameter & HSS $^{\mathbf{z}}$ & HSD $^{\mathbf{z}}$ & Shoot density & Leaf width & Leaf thickness & Leaf section \\
\hline Ball roll & $\mathrm{NS}$ & $\mathrm{NS}$ & $\mathrm{r}=-0.91^{* * *}$ & $\mathrm{NS}$ & $\mathrm{NS}$ & $\mathrm{r}=0.75^{*}$ \\
Hardness & $\mathrm{NS}$ & $\mathrm{NS}$ & $\mathrm{r}=-0.90^{* * *}$ & $\mathrm{NS}$ & $\mathrm{NS}$ & $\mathrm{N}=0.85^{* *}$ \\
Maximum hardness & $\mathrm{NS}$ & $\mathrm{NS}$ & $\mathrm{NS}$ & $\mathrm{NS}$ & $\mathrm{NS}$ \\
Maximum hardness depth & $\mathrm{r}=0.88^{* *}$ & $\mathrm{r}=-0.97^{* * *}$ & $\mathrm{r}=-0.70^{*}$ & $\mathrm{NS}$ & $\mathrm{N}=0.78^{*}$ \\
Traction & $\mathrm{r}=-0.72^{*}$ & $\mathrm{r}=0.72^{*}$ & $\mathrm{r}=0.70^{*}$ & $\mathrm{r}=0.93^{* * *}$ & $\mathrm{NS}$ \\
Vertical ball rebound & $\mathrm{NS}$ & $\mathrm{NS}$ & $\mathrm{r}=-0.76^{*}$ & $\mathrm{NS}$ & $\mathrm{r}=0.62^{*}$ & $\mathrm{r}=0.81^{* *}$ \\
Angular ball rebound & $\mathrm{NS}$ & $\mathrm{NS}$ & $\mathrm{r}=-0.73^{*}$ & $\mathrm{NS}$ & $\mathrm{r}=0.71^{*}$ & $\mathrm{r}=0.70^{*}$ \\
Shock absorption & $\mathrm{NS}$ & $\mathrm{NS}$ & $\mathrm{r}=0.87^{* *}$ & $\mathrm{NS}$ & $\mathrm{NS}$ & $\mathrm{r}=-0.79^{*}$ \\
Vertical deformation & $\mathrm{NS}$ & $\mathrm{NS}$ & $\mathrm{r}=0.90^{* *}$ & $\mathrm{NS}$ & $\mathrm{NS}$ & $\mathrm{r}=-0.81^{* *}$ \\
\hline
\end{tabular}

${ }^{\mathrm{z}} \mathrm{HSS}=$ horizontal stem section, HSD $=$ horizontal stem density.

Ns, $*, * *, * * *$ Nonsignificant or significant at $P \leq 0.05,0.01,0.001$, respectively.

Table 7. Pearson product-moment correlation coefficient $(r)$ between playing parameters (tests carried out 19 Sept. 2012) and leaf tissue compounds (leaf samples collected on 19 Sept. 2012) across the three tested species ('Tifway 419' hybrid bermudagrass, 'Zeon' manilagrass, 'Salam' seashore paspalum).

\begin{tabular}{lccc}
\hline Parameter & \multicolumn{1}{c}{ Dry wt } & Silica & Lignin \\
\hline Ball roll & $\mathrm{r}=-0.68^{*}$ & $\mathrm{NS}$ & $\mathrm{NS}$ \\
Hardness & $\mathrm{r}=-0.76^{*}$ & $\mathrm{NS}$ & $\mathrm{NS}$ \\
Maximum hardness & $\mathrm{NS}$ & $\mathrm{NS}$ & $\mathrm{NS}$ \\
Maximum hardness depth & $\mathrm{r}=-0.94^{* * *}$ & $\mathrm{r}=-0.96^{* * *}$ & $\mathrm{r}=-0.93^{* * *}$ \\
Traction & $\mathrm{r}=0.87^{* *}$ & $\mathrm{r}=0.84^{* *}$ & $\mathrm{r}=0.78^{*}$ \\
Vertical ball rebound & $\mathrm{r}=-0.69^{*}$ & $\mathrm{NS}$ & $\mathrm{NS}$ \\
Angular ball rebound & $\mathrm{NS}$ & $\mathrm{NS}$ & $\mathrm{NS}$ \\
Shock absorption & $\mathrm{r}=0.68^{*}$ & $\mathrm{NS}$ & $\mathrm{NS}$ \\
Vertical deformation & $\mathrm{r}=0.75^{*}$ & $\mathrm{NS}$ & $\mathrm{NS}$ \\
\hline
\end{tabular}

NS, $*, * *, * * *$ Nonsignificant or significant at $P \leq 0.05,0.01,0.001$, respectively.

deformation $(\mathrm{r}=0.75)$. Dry matter percentage was negatively correlated both with ball roll and vertical ball rebound $(\mathrm{r}=-0.68$ and $\mathrm{r}=-0.69)$ and positively correlated with traction $(\mathrm{r}=$ $0.87)$. Silica $(r=0.84)$ and lignin $(r=$ 0.78 ) were positively correlated with shear strength.

\section{Discussion}

All angular rebound values were above the minimum of 1.4 MPa previously recommended by van Wijk (1980). 'Salam' seashore paspalum had the hardest playing surface, probably derived from its low shoot density and HSD compared with 'Tifway 419' and 'Zeon', which probably deprives the 'Salam' pitch of a cushioning effect found in the other two species. This previously recorded (Lulli et al., 2012) lack (or relative thinness) of the horizontal stem layer (stolons and rhizomes) is exemplified by the depth at which the penetrographmeasured maximum hardness is measured, and by the low traction values, indicating that no dense and highlignin or high-silica layer is present near the surface. Generally, 'Salam' 
playing characteristic values fall within the currently accepted parameters for natural turf, but only the traction data fall within the FIFA 2-Star parameters, with the rest of the data set on FIFA-standard tests falling within the FIFA 1-Star range. This confirms 'Salam' as a variety that is not well suited to the obtainment of high-end football pitches, confining its use to specific situations in which 'Salam' high salinity resistance dictates its use.

'Tifway 419' and 'Zeon' returned very similar results (often not significantly different) in terms of ball roll, hardness, vertical ball rebound, shock absorption, and vertical deformation.

'Zeon' returned a much higher traction value compared with 'Tifway $419^{\prime}$ and this could probably be explained by the significant differences in HSD and in maximum hardness depth, indicating for 'Zeon' the presence of a much denser and shallower horizontal stem system that induces a higher shear strength. In general, all playing parameter values for 'Zeon' and 'Tifway 419' fall within the accepted ranges for natural turf, and with data set on FIFAstandard tests falling within the FIFA 2-Star range (with the exception of a narrow fail by both on excessive shock absorption that could be managed with silica sand topdressings, or by lowering the mowing height). This confirms 'Tifway 419 ' as the $\mathrm{C}_{4}$ variety that is best suited to football pitch construction for Mediterranean areas (Miele et al., 2000), but also brings 'Zeon' into the group of acceptable species for the construction of football pitches (at least from a playing characteristics standpoint).

All the above considerations on the suitability of the three species to the adoption in the construction or conversion of football surfaces in the Mediterranean areas are strictly limited to their playing characteristics, and do not take into consideration other very important agronomical factors, such as wear resistance and recovery.

Three parameters could often be correlated with playability parameters: shoot density, leaf section, and dry matter. The cushioning effect generated by higher shoot densities shows through strong negative correlations with ball roll, vertical ball rebound, and angle ball rebound. In accordance with various previous studies

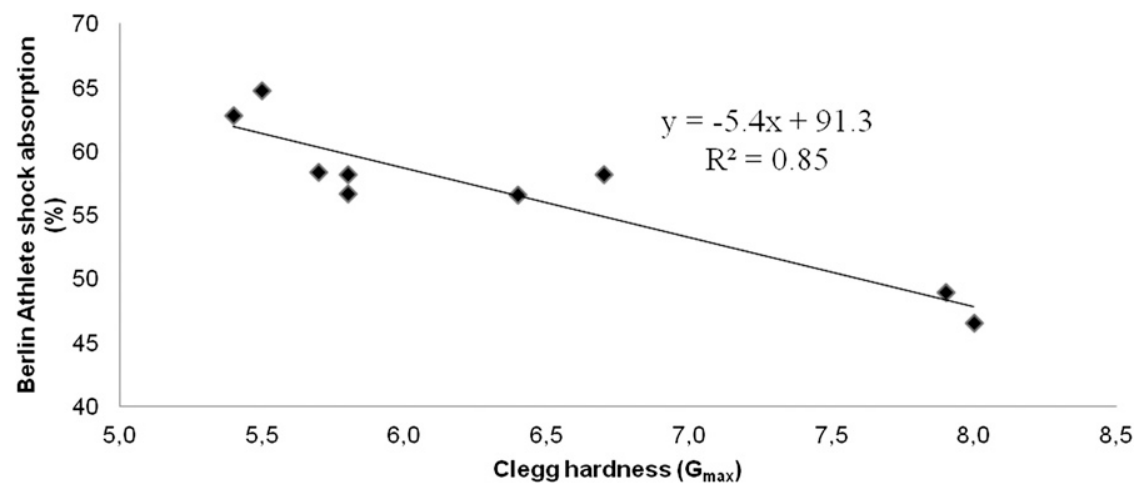

Fig. 1. Scatter diagram, linear regression equation, and coefficient of determination $\left(\mathrm{R}^{2}\right)$ for shock absorption measured with a Berlin Athlete and hardness [maximum negative acceleration on impact/acceleration due to gravity (Gmax), adimensional] measured with a Clegg impact soil tester data on the experimental plots of 'Tifway 419' hybrid bermudagrass, 'Zeon' manilagrass, and 'Salam' seashore paspalum to determine whether the two instruments (Berlin Athlete and Clegg impact soil tester) can be effectively interchanged in the measurement of soil/canopy hardness for sports fields.

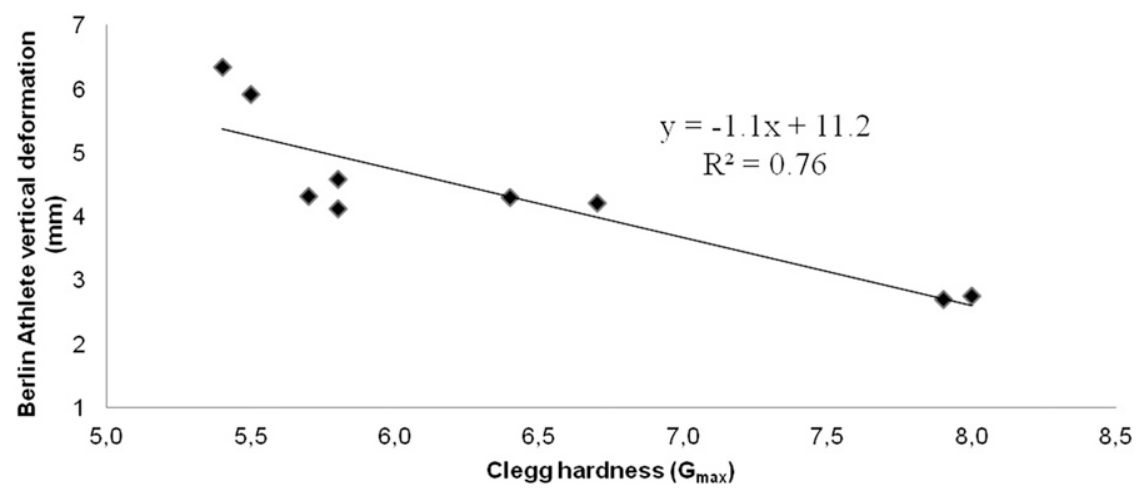

Fig. 2. Scatter diagram, linear regression equation, and coefficient of determination $\left(\mathbf{R}^{2}\right)$ for vertical deformation measured with a Berlin Athlete and hardness [maximum negative acceleration on impact/acceleration due to gravity (Gmax), adimensional] measured with a Clegg impact soil tester data on the experimental plots of 'Tifway 419' hybrid bermudagrass, 'Zeon' manilagrass, and 'Salam' seashore paspalum to determine whether the two instruments (Berlin Athlete and Clegg impact soil tester) can be effectively interchanged in the measurement of soil/ canopy hardness for sports fields; $1 \mathrm{~mm}=0.0394$ inch.

on 'Midiron' common bermudagrass [C. dactylon (Dunn et al., 1994)], traction was positively correlated with shoot density, probably due to the higher amount of plant biomass that football studs need to rip through during the test. Furthermore, previous studies on similar species (Roche et al., 2008) confirm that different traction values are to be expected when measuring similarly managed surfaces of different species. While the FIFA test method for rotational resistance has been described as less sensitive to bulk density differences in synthetic turf (Severn et al., 2011), in this trial, it proved to be adequately sensitive to some canopy architecture differences in natural turf. These results would also highlight the higher influence of canopy over soil in determining rotational resistance, at least in a situation of full green cover. The correlation between leaf section and playing parameters is probably related to organ architecture and can be explained by the two following hypothesis: 1) finer-leaved turfgrass species tend to generate canopies with a higher shoot density, hence the complementary influence of these two parameters (and the negative correlation of leaf width with rotational resistance); 2) thicker leaves could have a higher uniaxial compression resistance (and/or lower elastic 
modulus), determining a harder ballsurface and athlete-surface interaction, compared with finer (thinner) leaves. Furthermore, the stronger influence of leaf section on playing parameters, compared with leaf width and leaf thickness, could be interpreted as a measure of how much leaf tissue (square millimeters) actually interacts with ball or athlete, and how this amount of tissue appears to be influencing playing parameters.

According to the results obtained in this study, the only statistically significant correlation obtained by silica and lignin was with shear strength. This is probably due to the shear resistance imparted to leaves and horizontal stems by these two compounds (Dakora and Nelwamondo, 2003; Lulli et al., 2012), although specific trials would have to be carried out to confirm this hypothesis.

The results of this trial showed that surfaces of different $\mathrm{C}_{4}$ turfgrass species do generate different playability parameters and that these can be associated with certain specific canopy biometrical/morphological parameters such as shoot density, HSD, leaf section and, to a lesser extent, with certain plant tissue compounds that have proven mechanical properties (lignin, silica). As such, the monitoring of silica and lignin could represent a simple first screening when breeding species for certain specific mechanical traits.

Lastly, useful information could be gathered through the use of a penetrograph as far as maximum soil hardness is concerned, while all plant/ canopy biometrics and leaf compounds were found to correlate in a statistically significant manner with the depth of maximum hardness. This would indicate that fine, dense, highsilica and high-lignin canopies, with a dense weave of thin horizontal stems, generate a hard layer closer to the soil's surface, which is negatively correlated with shear strength $(\mathrm{r}=$ -0.79 , data not shown).

In this trial, the use of the Clegg impact soil tester was confirmed as a cheaper and easier to use alternative to the Berlin Athlete to carry out field investigations on soil/canopy hardness parameters, returning highly significant and negative linear association with both shock absorption $\left(\mathrm{R}^{2}=\right.$ $0.85, \mathrm{y}=-5.4 \mathrm{x}+91.3, P \leq 0.0004)$ and vertical deformation $\left(\mathrm{R}^{2}=0.76, \mathrm{y}=\right.$ $-1.1 \mathrm{x}+11.2, P \leq 0.0021$ ) (Figs. 1 and
2). As such, results would indicate that the simpler Clegg impact soil tester could effectively replace the Berlin Athlete for field testing of natural turfgrass surfaces. This option could prove very valuable in a foreseeable scenario of wider natural turf standardization and testing for adherence to sets of playability standards.

\section{Literature cited}

Alamar, M.C., R. Suay, and E. Moltó. 2008. Micromechanical behaviour of turfgrass for sports fields. Acta Hort. 783:303-308.

Baker, S.W. and P.M. Canaway. 1991. The cost-effectiveness of different construction methods for association football pitches. II. Ground cover, playing quality and cost implications. J. Sports Turf Res. Inst. 67:53-65.

Baker, S.W. and P.M. Canaway. 1993. Concepts of playing quality: Criteria and measurement. Intl. Turfgrass Soc. Res. J. 7:172-181.

Baker, S.W., R.J. Gibbs, and W.A. Adams. 1992. Case studies of the performance of different designs of winter games pitches. I. Playing quality and usage. J. Sports Turf Res. Inst. 68:20-32.

Baker, S.W. and A.R. Woollacott. 2005. Comparison of the playing performance of "third generation" synthetic grass with natural turf used for professional soccer. Intl. Turfgrass Soc. Res. J. 10:15-26.

Beard, J.B. 1973. Turfgrass: Science and culture. Prentice Hall, Englewood Cliffs, NJ.

Brinkmann, K., L. Blaschke, and A. Polle. 2002. Comparison of different methods for lignin determination as a basis for calibration of near-infrared reflectance spectroscopy and implications of lignoproteins. J. Chem. Ecol. 28:24832501.

Brosnan, J.T. and J. Deputy. 2007. Managing bermudagrass athletic fields. Univ. Hawaii, Honolulu, Dept. Tropical Plant Soil Sci. TM-6.

Brosnan, J.T. and J. Deputy. 2009. Preliminary observations on the traffic tolerance of four seashore paspalum cultivars compared to hybrid bermudagrass. HortTechnology 19:423-426.

Canaway, P.M. 1983. The effect of rootzone construction on the wear tolerance and playability of eight turfgrass species subjected to football-type wear. J. Sports Turf Res. Inst. 59:107-123.

Chivers, I. 2008. Turfgrass sports surfaces and their relationship to player injuries. Acta Hort. 783:115-132.
Clegg, B. 1976. An impact testing device for in situ base course evaluation. Austral. Road Res. Bur. Proc. 8:1-6.

Croce, P., A. De Luca, M. Mocioni, M. Volterrani, and J.B. Beard. 2004. Adaptability of warmseason turfgrass species and cultivars in a mediterranean climate. Acta Hort. 661:365-368.

Dakora, F.D. and A. Nelwamondo. 2003. Silicon nutrition promotes root growth and tissue mechanical strength in symbiotic cowpea. Funct. Plant Biol. 30:947-953.

Dunn, J.H., D.D. Minner, B.F. Fresenburg, and S.S. Bughrara. 1994. Bermudagrass and cool-season turfgrass mixtures: Response to simulated traffic. Agron. J. 86:10-16.

Elliott, C.L. and G.H. Snyder. 1991. Autoclave-induced digestion for the colorimetric determination of silicon in rice straw. J. Agr. Food Chem. 39:11181119.

European Council. 2009. Directive 2009/128 Establishing a framework for community action to achieve the sustainable use of pesticides. 21 Oct. 2009. $<$ http://eur-lex.europa.eu/legal-content/ $\mathrm{EN} / \mathrm{TXT} / \mathrm{PDF} /$ ? uri $=\mathrm{CELEX}$ : 32009L0128\&from $=\mathrm{EN}>$.

Féderation Internationale des Football Associations. 2012a. FIFA quality concept for artificial turf-Handbook of test methods. FIFA, Zurich, Switzerland.

Féderation Internationale des Football Associations. 2012b. FIFA quality concept for artificial turf-Handbook of requirements. FIFA, Zurich, Switzerland.

Grossi, N., M. Volterrani, S. Magni, and S. Miele. 2003. Tall fescue turf quality and soccer playing characteristics as affected by mowing height. Acta Hort. 661:319322.

Lulli, F., L. Guglielminetti, N. Grossi, R. Armeni, S. Stefanini, and M. Volterrani. 2011. Physiological and morphological factors influencing leaf, stolon and rhizome tensile strength in C4 turfgrass species. Funct. Plant Biol. 38:919-926.

Lulli, F., M. Volterrani, N. Grossi, R. Armeni, S. Stefanini, and L. Guglielminetti. 2012. Physiological and morphological factors influencing wear resistance and recovery in $\mathrm{C}_{3}$ and $\mathrm{C}_{4}$ turfgrass species. Funct. Plant Biol. 39:214-221.

Lulli, F., M. Volterrani, S. Magni, and R. Armeni. 2010. An innovative hybrid naturalsynthetic sports pitch construction system. Proc. Inst. Mechanical Eng. Part J. Sports Eng. Technol. 225:171-175.

Marcum, K.B. 1999. Salinity tolerance mechanisms of grasses in the subfamily Chloridoideae. Crop Sci. 39:1153-1160. 


\section{Preliminary and Regional Reports}

McNitt, A.S., P.J. Landschoot, and D.V. Waddington. 2003. Effects of turfgrass, cutting height and soil conditions on traction. Acta Hort. 661:39-48.

Miele, S., M. Volterrani, and N. Grossi. 2000. Warm season turfgrasses: Result of a five-year study in Tuscany. Agricultura Meditarranea 130:1-9.

Orchard, J., I. Chivers, D. Aldous, K. Bennell, and H. Seward. 2005. Ryegrass is associated with fewer non-contact anterior cruciate ligament injuries than bermudagrass. Brit. J. Sports Med. 39:704-709.

Pompeiano, A., N. Grossi, and M. Volterrani. 2012. Vegetative establishment rate and stolon growth characteristics of 10 zoysiagrasses in southern Europe. HortTechnology 22:114-120.

Roche, M.B., D.S. Loch, R.E. Poulter, and L.C. Zeller. 2008. Measuring the traction profile on sports fields: Equipment development and testing. Acta Hort. 783:399-414.

Rogers, J.N. and D.V. Waddington. 1989. The effect of cutting height and verdure on impact absorption and traction characteristics in tall fescue turf. J. Sports Turf Res. Inst. 65:80-90.

Severn, K.A., P.R. Fleming, J.D. Clarke, and J.M. Carré. 2011. Science of synthetic turf surfaces: Investigating traction behaviour. Proc. Inst. Mechanical Eng. Part J. Sports Eng. Technol. 225:147-158.
Shearman, R.C. and J.B. Beard. 1975. Turfgrass wear tolerance mechanisms: I. Wear tolerance of seven turfgrass species and quantitative methods for determining turfgrass wear injury. Agron. J. 67:208211 .

Trenholm, L.E., R.N. Carrow, and R.R. Duncan. 2000. Mechanisms of wear tolerance in seashore paspalum and bermudagrass. Crop Sci. 40:1350-1357.

van Wijk, A.L.M. 1980. A soil technological study on effectuating and maintaining adequate playing conditions of grass sports fields. Ctr. Agr. Publ. Documentation, Wageningen, Netherlands. 